Columbia Law School

Scholarship Archive

\title{
Free Markets, State Involvement, and the WTO: Chinese State Owned Enterprises (SOEs) in the Ring
}

Petros C. Mavroidis

Columbia Law School, petros.mavroidis@unine.ch

Merit E. Jano

Columbia University School of International \& Public Affairs (SIPA), mj60@columbia.edu

Follow this and additional works at: https://scholarship.law.columbia.edu/faculty_scholarship

Part of the International Trade Law Commons, and the Law and Economics Commons

\section{Recommended Citation}

Petros C. Mavroidis \& Merit E. Jano, Free Markets, State Involvement, and the WTO: Chinese State Owned Enterprises (SOEs) in the Ring, EUROPEAN UNIVERSITY INSTITUTE, ROBERT SCHUMAN CENTRE FOR AdVANCED Studies, Global Governance Programme Working Paper No. RSCAS 2017/13 (2017).

Available at: https://scholarship.law.columbia.edu/faculty_scholarship/2361

This Working Paper is brought to you for free and open access by the Faculty Publications at Scholarship Archive. It has been accepted for inclusion in Faculty Scholarship by an authorized administrator of Scholarship Archive. For more information, please contact scholarshiparchive@law.columbia.edu. 

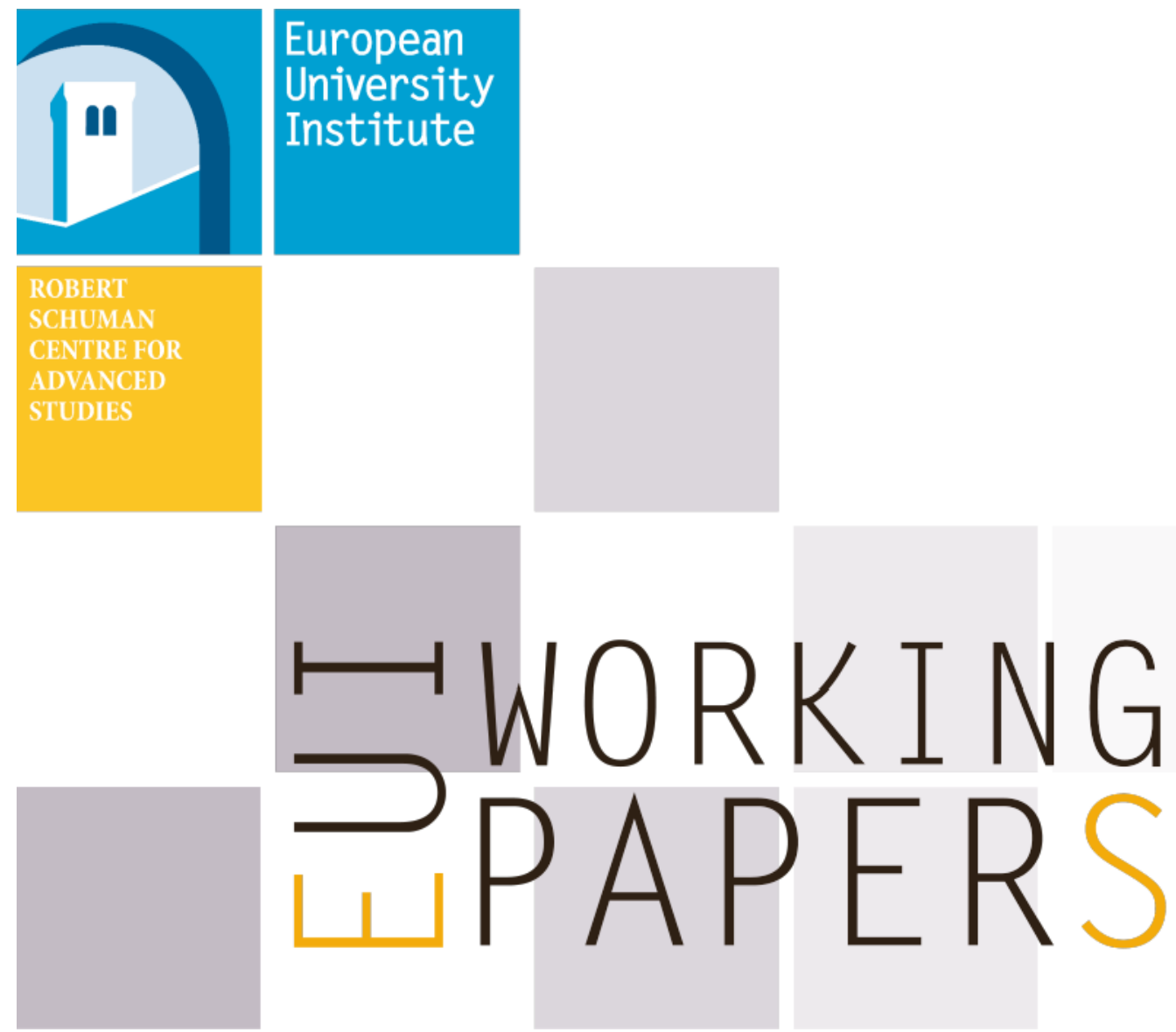

RSCAS 2017/13

Robert Schuman Centre for Advanced Studies Global Governance Programme-256

Free Markets, State Involvement, and the WTO: Chinese State Owned Enterprises (SOEs) in the Ring

Petros C. Mavroidis and Merit E. Janow 
European University Institute

Robert Schuman Centre for Advanced Studies

Global Governance Programme

Free Markets, State Involvement, and the WTO:

Chinese State Owned Enterprises (SOEs) in the Ring

Petros C. Mavroidis and Merit E. Janow

EUI Working Paper RSCAS 2017/13 
This text may be downloaded only for personal research purposes. Additional reproduction for other purposes, whether in hard copies or electronically, requires the consent of the author(s), editor(s). If cited or quoted, reference should be made to the full name of the author(s), editor(s), the title, the working paper, or other series, the year and the publisher.

ISSN 1028-3625

(C) Petros C. Mavroidis and Merit E. Janow, 2017

Printed in Italy, March 2017

European University Institute

Badia Fiesolana

I - 50014 San Domenico di Fiesole (FI)

Italy

www.eui.eu/RSCAS/Publications/

www.eui.eu

cadmus.eui.eu 


\section{Robert Schuman Centre for Advanced Studies}

The Robert Schuman Centre for Advanced Studies (RSCAS), created in 1992 and directed by Professor Brigid Laffan, aims to develop inter-disciplinary and comparative research and to promote work on the major issues facing the process of integration and European society.

The Centre is home to a large post-doctoral programme and hosts major research programmes and projects, and a range of working groups and ad hoc initiatives. The research agenda is organised around a set of core themes and is continuously evolving, reflecting the changing agenda of European integration and the expanding membership of the European Union.

Details of the research of the Centre can be found on:

http://www.eui.eu/RSCAS/Research/

Research publications take the form of Working Papers, Policy Papers, Policy Briefs, Distinguished Lectures, Research Project Reports and Books.

Most of these are also available on the RSCAS website:

http://www.eui.eu/RSCAS/Publications/

The EUI and the RSCAS are not responsible for the opinion expressed by the author(s).

\section{The Global Governance Programme at the EUI}

The Global Governance Programme is one of the flagship programmes of the Robert Schuman Centre for Advanced Studies at the European University Institute (EUI). It aims to: build a community of outstanding professors and scholars, produce high quality research and, engage with the world of practice through policy dialogue. At the Global Governance Programme, established and early career scholars research, write on and discuss, within and beyond academia, issues of global governance, focussing on four broad and interdisciplinary areas: European, Transnational and Global Governance; Global Economics; Europe in the World; and Cultural Pluralism.

The Programme also aims to contribute to the fostering of present and future generations of policy and decision makers through its unique executive training programme, the Academy of Global Governance, where theory and "real world" experience meet. At the Academy, executives, policy makers, diplomats, officials, private sector professionals and academics, have the opportunity to meet, share views and debate with leading academics, top-level officials, heads of international organisations and senior executives, on topical issues relating to governance.

For more information: http://globalgovernanceprogramme.eui.eu 



\begin{abstract}
The WTO has struggled with the treatment of nonmarket economies (NMEs). What was a nonissue in the original GATT (because of the homogeneity of participants) became quite an issue with the accession of formally centrally planned economies, which were not transformed to market economies, at least not in the eyes of the incumbents. Contracting this issue has proved to be so far always wanting, and leaving it to adjudicators has not produced good results either. With respect to Chinese SOEs this risks continuing to be an issue, since the contractually agreed deadline (2016) after which China should not be treated as NME anymore, risks proving to be full of holes and loopholes.
\end{abstract}

\title{
Keywords
}

NME (nonmarket economy); SOE (state-owned enterprise); WTO.

JEL Classification: K40; F13 



\section{Property Regime and the WTO}

Issues surrounding the operation of state owned enterprises in the international trading system is an understudied area and yet one of increasing importance, particularly given the size and significance of Chinese state owned enterprises (SOE). We start by situating the SOE within the GATT and WTO frameworks and then summarize the main findings of a set papers prepared for an advanced law and policy seminar on SOEs held at Columbia Law School in the fall 2016.

By way of introduction, it is important to remember that the GATT (General Agreements on Tariffs and Trade), the predecessor of the WTO (World Trade Organization), did not contain any provisions to differentiate between approaches to property rights at the domestic level. The assumption was that members of the GATT would be free markets (as opposed to centrally planned economies, or non market economies - NMEs for short).

The GATT did not, however, close its doors to centrally planned economies. Indeed, Poland and Romania joined the GATT and did not change the fundamental character of their centrally planned systems. With the triumph of liberal ideas in the late ' 80 s and early ' 90 s, a number of former NMEs adopted free market policies and joined the WTO, which came into being on January 1, 1995. Causality is hard to determine, however, i.e., whether countries first abandoned their NME status and joined the WTO or whether joining the WTO contributed to their evolution away from planning.

Indeed, quite a variety of economic systems came to join the WTO, which did not oblige uniform national approaches to trade or investment. Indeed, this lack of a harmonization requirement has often been seen as a central strength of the GATT and WTO architecture. The WTO, contrary to the GATT, adopted the practice of negotiating elaborate protocols of accession for NMEs, aimed at addressing issues specific to the NME that was joining the WTO, until (the hope was) they would evolve into market economies. This is by way of brief background for the following discussion of the GATT/WTO architecture around SOEs.

\section{GATT: Solving the Problem by Participation}

The GATT was negotiated at a point in time when the only major NME of significance was the USSR (Union of Soviet Socialist Republics). Because the USSR declined the invitation to join the GATT, the architecture of the GATT did not have to think long and hard about addressing NME-related issues.

\subsection{Canada Suggests Only Like-Minded Should be Invited}

A brief review of history reminds us that following a Canadian proposal to this effect, ${ }^{1}$ the instigators of the GATT issued an invitation to participate in the upcoming negotiations only to like-minded countries - and this essentially meant market economies. This approach was thought by some to be too narrow an approach and going against the Hullian idea of pursuing liberalization of trade as an instrument to foster peace and security. ${ }^{2}$ The eventual compromise, as reported at length in Irwin et al. (2008), was to keep the door open. Accordingly, an invitation to join the GATT was consequently issued to the USSR.

See the relevant discussion in Irwin et al. (2008).

2 Cordell Hull, the US Foreign Secretary during the Roosevelt Administration, and Nobel Prize laureate for his contribution to post WWII peace, was adamant that trade liberalization was the safest way in establishing communication across nations, and thus contribute meaningfully to peace. Irwin et al. (2008) provide a lot of evidence to this effect. 


\subsubsection{Back to the USSR}

By 1946, when the GATT was under negotiation, the USSR had already rejected the market opening ideas of Lenin and its New Economic Policy (NEP). It had become a closed system that would engage in international trade only with members of its alliance. Churchill described this situation in his famous speech of March 5, 1946:

From Stettin in the Baltic to Trieste in the Adriatic, an iron curtain has descended across the continent.

Unsurprisingly thus, upon receipt of the invitation to join the GATT, the USSR declined it. The road was thus open to negotiate the GATT across like-minded players, albeit with one, last minute point of friction.

\subsubsection{Czechoslovakia Switches Camps, Then Leaves}

Czechoslovakia was a free market when the GATT negotiations were initiated. Following the Yalta Agreement and the ensuing establishment of the 'Iron Curtain', the dividing line between market economies and NMEs in Europe, it switched camps. Czechoslovakia did not immediately withdraw from the negotiations. It eventually decided not to sign the GATT, which it then joined only decades later in 1993 after its transition to market economy (in fact, its two components joined the WTO namely, the Czech- and the Slovak Republic through separate acts of accession).

\subsection{Statutory Provisions Regarding NMES}

The United Kingdom (UK) was a key participant in the early negotiations. Although the leading economist of his generation, John Maynard Keynes, did not participate in the GATT negotiation because of his untimely death, he had ample time during the Bretton Woods negotiations to express his views on the role of government when conducting international trade. According to Irwin et al. (2008) on p. 18:

Keynes strongly believed that government economic planning would be required to ensure full employment in the postwar period. Such planning, in his view, would necessarily include government controls on international trade. ${ }^{3}$ The State Department and other U.S. agencies took a very different view. Not only did they want nondiscrimination as a key part of the world trading system, but they also wanted to ensure that most international trade would be left in the hands of private enterprise, not government planners.

Chief among the provisions regarding the role of the state in trade relations, was Article XVII of GATT regarding the function of state-trading enterprises (STEs). Its key features provide:

... a State enterprise ... shall, in its purchases or sales involving either imports or exports, act in a manner consistent with the general principles of non-discriminatory treatment ... require that such enterprises ... make any such purchases or sales solely in accordance with commercial considerations, ${ }^{*} \ldots$ and shall afford the enterprises of the other contracting parties adequate opportunity, in accordance with customary business practice, to compete for participation in such purchases or sales (emphasis added)

An economic official at the U.S. Embassy in London, E. F. Penrose $(1953,18)$, recalled about this period: "At that time and later I did my best to impress on Mr. Keynes and other government economists that the desire for freer and for nondiscriminatory trade in the State Department should not be written off as the product of a nineteenth century laissez-faire attitude toward economic affairs, untouched by recent economic thought and experience. . . . In conversations in Washington both Acheson and Hawkins showed themselves progressive in outlook and under no illusion that freer trade alone was panacea for all economic ills. However, it soon appeared that the contrary view had been expressed to British officials in Washington by some U.S. officials outside the State Department." Markwell (2006) provides a good study of Keynes's views on international economic matters. 
Eventually, another provision was added in the form of an Interpretative Note to Article VI of GATT.

\subsubsection{Article XVII of GATT}

The UK and Canada were the leaders of the discussion of this provision, which aimed to discipline trading nations that conducted trade through state entities. Wheat Boards, for example, were very much in vogue around that time aiming to stabilize fluctuating prices of farm goods. The provision imposed a nondiscrimination obligation on STEs, and, in the second paragraph, an obligation for them to act in accordance with commercial considerations, and to afford adequate opportunities to competitors.

Case law has substantially weakened the 'bite' of this provision, by finding that it suffices for STEs to act in a nondiscriminatory manner. In this view, by acting in this manner, STEs had ipso facto acted in accordance with commercial considerations, and had afforded competitors adequate opportunities to compete as well. This view is, of course, at best doubtful, but by now it is water under the bridge, since there is not one single deviation from this case law. ${ }^{4}$

\subsubsection{Article VI of GATT}

The Interpretative Note to Article VI of GATT ${ }^{5}$ provides for the possibility to deviate from standard antidumping procedures when dealing with exporters originating in NMEs. The interesting feature of this provision is that it provides for a definition of NMEs:

It is recognized that, in the case of imports from a country which has a complete or substantially complete monopoly of its trade and where all domestic prices are fixed by the State ...

This is a very demanding provision. By this standard, one might in principle wonder if there is even one nation on earth at the present time that qualifies as an NME. And yet, in application, the practice has proven flexible. This provision has been used against Eastern European countries, as well as China and some of its neighbors.

\subsubsection{End Result: Much Ado about Nothing (but Something is Around the Corner)}

Given this history, it follows that the GATT regime did not address the issue of state trading or the operation of firms in non-market economies in a comprehensive manner. It was not much of an issue, in any event, in the early days given the small membership of the GATT. Over time, however, as many more countries joined into the system, the systemic consequences of limited provisions on NMEs have become more significant and apparent.

\subsection{Subsequent Accessions}

Prior to the negotiation of the Uruguay Round, only two NMEs joined the GATT, namely, Poland (1967) and Romania (1971). They signed protocols of accession where they accepted a few additional obligations, but nothing very comprehensive or dramatic. They continued as NMEs until the fall of the Berlin Wall, and the beginning of their negotiation to accede to the European Union (Williams 2008).

\footnotetext{
4 Mavroidis (2016) discusses the case law to this effect. The leading case is Canada-Wheat Exports and Grain Imports, issued in 2004, where the Appellate Body understood the obligation to not discriminate as the overarching obligation, and the obligations to "act in accordance with commercial consideration", and to "afford adequate opportunities to compete" as mere expressions of the obligations to not discriminate, and not as distinct legal obligations.

5 Jackson (1969) discusses this provision, its birth and original idea in detail.
} 
For much of its early history the GATT was overwhelmingly comprised of western nations and there was no perceived need to develop comprehensive provisions to address what seemed to be a nonissue.

\title{
3. Solving the Problem by Contracting
}

This changed with the WTO. One hundred and twenty three nations signed onto the WTO initially, and many of them were not full market economies. Given the limited coverage of relevant provisions under the rules of the GATT, trading nations chose to add additional disciplines through the contracting process of the negotiation of protocols of accession. Disciplines were agreed both at the multilateral as well as the preferential level.

\subsection{Multilateral Solutions (WTO)}

The WTO, as per its custom to minimize negotiating costs, did not address the issue of SOEs in a horizontal manner. It did not amend existing provisions. It preferred to address selected issues on an ad hoc basis by allowing incumbents to negotiate deals with acceding nations. The means to do this were offered by the new, lengthy Protocols of Accession.

NME-status, if we take the statutory definition seriously, does not only arise in the case of the China. Many WTO members meet the definitional standard. Nevertheless, only the Chinese Protocol of Accession includes elaborate provisions on NMEs. Indeed, the Russian Protocol of Accession pales in comparison, as do the protocols of some Gulf countries with elaborate sovereign wealth funds and other state run entities.

Why is China the issue? As evident in discussion after discussion in our seminar, the answer can be found in two words: "size matters". China accepted to be treated until 2016 an NME, and avoided thus the negotiation of disciplines that would oblige it to precommit to a particular market structure by a date certain. Title 15 of its Protocol of Accession (Price Comparability in Determining Subsidies and Dumping) reads:

\begin{abstract}
Once China has established, under the national law of the importing WTO Member, that it is a market economy, the provisions of subparagraph (a) shall be terminated provided that the importing Member's national law contains market economy criteria as of the date of accession. In any event, the provisions of subparagraph (a)(ii) shall expire 15 years after the date of accession. In addition, should China establish, pursuant to the national law of the importing WTO Member, that market economy conditions prevail in a particular industry or sector, the non-market economy provisions of subparagraph (a) shall no longer apply to that industry or sector.
\end{abstract}

It is not entirely clear why 2016 was selected as the date when China would no longer be treated as an NME. Some of the papers presented in our seminar (Levy) have advanced the argument that, presumably, WTO members might have thought that between 2001, the year of Chinese accession to the WTO, and 2016, the reforms that were then underway would have translated into a fully functioning market economy, whatever ultimate beneficial ownership may still exist.

More generally, as some of the essays herein amplify, China agreed in its Protocol to far reaching provisions around its domestic trade and economic system. For example, in article 9 of its Protocol it committed to "allow prices for traded goods and services in every sector to be determined by market forces"; in Article 5.1 it committed to "progressively liberalize the availability and scope of the right to trade, so that within three years after accession all enterprises in China shall have the right to trade in goods"; it further committed in article 6.1 that "import purchasing procedures of state trading enterprises are fully transparent". As evidenced by these and other provisions, China's Protocol was perhaps the most ambitious and far reaching set of commitments of any developing country that has joined the international trading system. 


\subsection{Preferential Trade Agreements}

There is not much practice regarding the treatment of NMEs in the context of preferential trade agreements. A recent and fairly comprehensive approach is offered by the definition of SOEs in TPP (Trans-Pacific Partnership). TPP was negotiated by the countries around the Pacific Rim, but China was not part of the negotiation and, as a result, it could not influence its structure and outcome. Bhala (2017) discusses in detail the TPP definition of NMEs in this volume. As he explains, the TPP definition of NMEs clearly departs from the WTO case law understanding regarding the nature of obligations imposed on the state sector.

\subsection{The Road Ahead}

We are now in early 2017, and China has already initiated litigation to have WTO judges decide whether the 2016 deadline has to be honored. Is 2016 the end of the road for China as an NME?

It is always difficult to predict how the Appellate Body might decide on a question before it but in EC-Fasteners the Appellate Body appears to have opened the door to treat China as an NME even after 2016. Bown and Mavroidis (2013) suggested that the onus will be on complainants who will have to demonstrate that states influence prices. Their argument, briefly, is that by including 2016 as some sort of 'expiration date' for treating China as an NME, WTO members did not give up on their right to do so after 2016 as well. This date should be understood differently. WTO members can treat China as an NME until 2016 without adducing any evidence to this effect, that is, by merely invoking the statutory provision in the Protocol of Accession. After 2016, they can continue to do the same, but in this case, they will have to honor the associated burden of proof, that is, they will have to show that the Chinese state has influenced prices, and the latter are not the reflection of a market clearing mechanism.

This is not a far-fetched theory as it simply cannot be that the NME provision applies in principle to everyone but not to China. In theory any jurisdiction could be treated in this way, such as the US following the introduction of TARP (Troubled Asset Relief Program), or the EU when heavily subsidizing some of its sectors. If so, why not China?

By this reading, 2016 would mean that China will not automatically be treated as an NME. Those who want to apply the rules around NMEs would have to make the case for it. But this particular set of issues has to do with the standards that will apply with respect to contingent protection, which is reviewed on a case by case basis. WTO's main contribution is to address conditions that affect international trade more broadly; it is not designed to address rivalry within markets. Other instruments (such as antitrust or competition laws) are meant to address similar concerns within markets.

How are SOEs affecting access to foreign imports? Is this covered by the rules of the WTO? Has China established a fully transparent trade regime? Needless to say, these are some of the complex and new questions being raised by Chinese commercial entities.

\section{Contributions on China and SOEs prepared for the law and policy seminar}

Papers addressed three broad themes: first, the substantive economic and trade regime; second, the intersection between trade and competition policy, and third, transparency of and dispute adjudication relating to SOEs.

\subsection{The Substantive Trade Regime}

Lin (2017) explains the manner in which SOEs operate and their oversight by different state entities, providing an excellent background for understanding the main challenges to the world trading system 
presented by SOEs. Lin provides a comprehensive anatomy of Chinese SOEs by unpacking their various relations with different instruments of the state. She shows that Chinese SOEs are embedded in a network composed of dense and complex links with the state. Shareholding ties, albeit important, are only one feature of potential state influence or control. She illustrates important governance institutions that are unobservable (e.g., they have no statutory underpinnings), and are quite distinct from approaches elsewhere in the world. In doing that, she explains the role of state intervention in administering SOEs, particularly through the SASAC (State-Owned Assets Supervision and Administrative Commission of the State Council), a state entity responsible for administration of SOEs.

Mastromatteo (2017) discusses Article XVII of GATT. He notes that, by acting as a trader, a government may influence the direction of international trade through its purchases and sales decisions without resort to other more direct means of trade regulation. The GATT recognizes that governments may choose to participate in international commerce in competition with private firms, but it does not leave them with a free hand when it comes to carrying out trading operations. In the 70 years since their adoption, developments in both the GATT 1947 and the WTO have delineated a set of relatively limited disciplines rooted in the principle of nondiscrimination, raising doubts about their effectiveness to address the kinds of problems caused by state trading today. It remains true, however, that while STEs continue to operate across the world, and fundamental questions about the full reach and scope of the existing disciplines endure, opportunities to clarify their role in the modern trading system may well arise in the future practice of WTO members.

Prusa (2017) focuses on the other core GATT provision, the Interpretative Note as Article VI, and the manner in which NMEs have fared in WTO antidumping practice. In his paper, he aims to show that, whereas the statutes allow investigating authorities more leeway when dealing with NMEs, abuses have been condemned in case law. To do this, he focuses in a very important litigation that occurred in 2007, when the US reversed its long-standing policy prohibiting the simultaneous imposition of anti-dumping duties (ADDs) and countervailing duties (CVDs) against nonmarket economies. The EU followed the US' lead and also began imposing simultaneous ADDs and CVDs. The practice, however, leads to double remedies. The WTO Appellate Body recently ruled that double remedies were inconsistent with the Agreement on Subsidies and Countervailing Measures (SCM) and that the burden was on the investigating authorities to ensure that double remedies were not being imposed.

In a companion paper, Lee (2017) focuses on the issue whether Chinese SOEs should be considered to be a 'public body' in the sense of the SCM Agreement. A positive response would entail that the SCM disciplines apply to SOEs. This is an issue that has occupied the minds of WTO judges for some time now, and case law is not characterized by internal coherence either. Lee explains the various transformations of case law in this respect, as well as its current status. In his view, a sophisticated 'control'-criterion seems appropriate, and he advances a few thoughts regarding the manner in which it should be practiced.

Levy (2017) discusses the manner in which SOEs have been handled in Protocols of Accession. His main conclusion is that they have not been handled particularly well. He notes that the treatment in the text of the Chinese Protocol was very brief, and essentially offered particular China-specific adjustments to existing WTO agreements, such as the Agreement on Subsidies and Countervailing Measures (SCM). Those agreements had often been inadequate to handle the issues faced by a preChina WTO and the tweaks were insufficient to handle the additional problems posed by China. In many cases, foreseeable problems were simply not addressed at all in the Protocol. Unsurprisingly, thus, we end up in the current state, where no jurisdiction seems to be happy with the regulation of SOEs.

Bhala (2017) focuses on how regional initiatives, and specifically the Trans-Pacific Partnership (TPP), have tried to avoid the shortcomings of the multilateral (inadequate) regulation of SOEs. Free 
trade agreements (FTAs) are about far more than free trade, he notes. They are often about national security as well. Against this background, he makes two points. First, TPP exemplifies the possibility of enhancing US national security objectives. Advancement of such objectives may occur through the containment of China and its ruling Chinese Communist Party (CCP). Second, the debate over the definition of SOE is one among many illustrations in TPP of the link between national security, trade, and containment. The 12 nations negotiating TPP were aware of this link, and deliberated on the definition of SOE. TPP parties did not include China amongst its founding members, even as the founding members wrote TPP rules that would bind China if it subsequently joined the deal. Chinese SOEs were of concern to the negotiating parties to the TPP for both economic and national security reasons. In addition, a number of TPP parties had their own sovereign interests in providing goods and services through their own SOEs. The evaluation by America and its 11 TPP partners as to which entities should be included in the scope of SOE disciplines, produced, for the first time, a set of clear rules.

\subsection{Trade and Competition Issues}

A second cluster of papers considered the competition issues associated with SOEs. Wu (2017) discusses why, despite the fact that China's WTO Protocol of Accession imposes several restrictions on China's use of export policies to support domestic industries, China's trading partners nevertheless regularly bemoan Chinese practices. In his contribution, Wu examines a series of Chinese export policies that have been the subject of WTO complaints. He discusses several elements of WTO law that render the WTO largely ineffective in confronting these practices. He argues that, because of domestic constraints and negotiating stasis, it is unlikely that the WTO system will undertake any major reforms to address these shortcomings. He concludes that as a consequence, tensions are likely to continue rising between China and its trading partners.

Kovacic (2017) focuses on the extent of rivalry within the Chinese market, and the significant and broad policy developments emerging from the $3^{\text {rd }}$ Plenum, namely the decisions to establish a competitive economy, and at the $4^{\text {th }}$ Plenum to advance the rule of law. These reforms are necessary to achieving China's strategic economic objectives, and to its successful and rapid transition to become a high income economy. If adopted, the author argues, the two main outcomes of the reforms would be, first, a reduction in the size and scope of the uncompetitive regulated sub-economy and a corresponding, inverse increase in the size and scope of the competitive sub-economy; and second, a strengthened competition law and policy regime that can be more effectively enforced throughout the national economy without discrimination by ownership or industry. Both these outcomes would help China to exploit more fully the country's latent economic potential, and to achieve high, robust and sustainable growth rates based on efficiency, innovation and international competitiveness. They would also ensure China's 'Market Economy Status' in global economic relations.

\subsection{Transparency and Adjudication}

A third set of papers explore the question whether the solution to the challenges posed by SOEs is better served through increased transparency, or conversely, whether reform can be best achieved through adjudication.

Wolfe (2017) notes that SOEs are a major force in the Chinese economy and a growing presence in international trade and investment. Thus, the challenge to the WTO legal regime is both commercial, given their size and their share of Chinese output, and political, given worries that trade and investment by SOEs may be driven by public policy goals. And both challenges may be exacerbated by the murky world of Chinese SOEs. He first addresses the question whether Chinese SOEs are a problem for the WTO, and whether more sunshine on their operations might be a useful discipline. He then asks what we know about SOEs inside the WTO, including in the Trade Policy Review Mechanism. Since the answer is, in his view, that these mechanisms offer little guidance or insight, he 
consider whether mega-regional trade negotiations offer a better approach. His answer being negative, he finally considers whether an attempt to negotiate a WTO Reference Paper on SOEs might help. He concludes that transparency is likely to be a better discipline on the spillovers associated with SOEs than a search for binding rules, while also helping everyone better understand the efficiency effects.

Trachtman (2017) addresses the broad category of industrial policy conflicts between China and the United States, with subsections focusing on discrete issues such as discrimination, subsidies, dumping, export restrictions, exchange rate management, and state owned enterprises. He further addresses conflicts that have arisen because of concerns relating to security policy, and then examines how U.S. and Chinese preferential trade agreement initiatives have sought to gain advantage in these areas - a kind of strategic forum shopping - recognizing that the new U.S. administration is unlikely to move forward with the Trans-Pacific Partnership. He argues that international law can be used in two ways: to promote short-term national advantage in particular disputes, and/or to support rules that benefit all, with the expectation that over the long term, this will best promote national advantage. China and the U.S., the author claims, can lead the world in formulating and using WTO law. If they both engage in long-term support of beneficial trade rules, they will both prosper more in the long run.

In conclusion, the set of essays comprise a multi-faceted examination of SOEs in the international trading system. It is a subject of importance to the further integration of China into the world trading system but has broader implications for all jurisdictions where state enterprises continue to be a significant area of economic activity. 


\section{References}

Bhala, Raj. 2017. TPP, American National Security and Chinese SOEs. EUI RSCAS WP 2017/03.

Bown, Chad P., and Petros C. Mavroidis. 2013. One (Firm) is not Enough: a Legal-Economic Analysis of EC-Fasteners, The World Trade Review, 12: 243-272.

Irwin, Douglas A., Petros C. Mavroidis, and Alan O. Sykes. 2008. The Genesis of the GATT, Cambridge University Press: New York City, New York.

Jackson, John H. 1969. World Trade and the Law of the GATT, Bobbs-Merrill: Indianapolis, Indiana.

Levy, Phil. 2017. The Treatment of Chinese SOEs in China's WTO Protocol of Accession.

Lin, Li-Wen. 2017 A Network Anatomy of Chinese State-Owned Enterprises. EUI RSCAS WP 2017/07.

Mastromatteo, Andrea. 2017. WTO and SOEs: Overview of Article XVII and related provisions of the GATT 1994. EUI RSCAS WP 2017/08.

Mavroidis, Petros C. 2016. The Regulation of International Trade, MIT Press: Cambridge, Massachusetts.

Penrose, Ernest F. 1953. Economic Planning for the Peace. Princeton, NJ: Princeton University Press.

Prusa, Thomas. 2017. NMEs and The Double Remedy Problem. EUI RSCAS WP 2017/10.

Trachman, Joel. 2017. U.S.-Chinese Trade: Interface and Lawfare. EUI RSCAS WP 2017/11.

Wolfe, Robert 2017. Sunshine over Shanghai: Can the WTO illuminate the murky world of Chinese SOEs? EUI RSCAS WP 2017/12.

Williams, Peter. John. 2008. A Handbook on Accession to the WTO, a WTO Secretariat Publication, Cambridge University Press: Cambridge, United Kingdom. 


\section{Author contacts:}

\section{Petros C. Mavroidis}

Edwin B. Parker Professor of Law at Columbia Law School and Professor of Law at the University of Neuchâtel, respectively;

Email: Petros.Mavroidis@unine.ch

\section{Merit E. Janow}

Dean and Professor in the Practice of International Economic Law \& International Affairs School of International and Public Affairs (SIPA)

Columbia University

Email:mj60@columbia.edu 